\title{
Finance and Income Inequality: What Do the Data Tell Us?
}

\author{
George R. G. Clarke, ${ }^{*}$ Lixin Colin Xu, $\uparrow$ and Heng-fu Zou $\ddagger$
}

\begin{abstract}
Although there are distinct conjectures about the relationship between finance and income inequality, little empirical research compares their explanatory power. We examine the relationship between finance and income inequality for 83 countries between 1960 and 1995. Because financial development might be endogenous, we use instruments from the literature on law, finance, and growth to control for this. Our results suggest that, in the long run, inequality is less when financial development is greater, consistent with Galor and Zeira (1993) and Banerjee and Newman (1993). Although the results also suggest that inequality might increase as financial sector development increases at very low levels of financial sector development, as suggested by Greenwood and Jovanovic (1990), this result is not robust. We reject the hypothesis that financial development benefits only the rich. Our results thus suggest that in addition to improving growth, financial development also reduces inequality.
\end{abstract}

JEL Classification: D3, G2, 01

\section{Introduction}

Recent studies have shown that financial sector development boosts economic growth (Levine 1997b). ${ }^{1}$ But many people worry that financial development benefits only the rich and powerful. Because financial markets are fraught with adverse selection and moral hazard problems, borrowers need collateral. The poor, who do not have this, might, therefore, find it difficult to get loans even when financial markets are well developed. In contrast, the rich who do have property that can be used as collateral might benefit as the financial sector develops. If financial development improves access for the rich, but not the poor, it might worsen inequality.

But this might not be the case. As the financial sector grows, the poor, who were previously excluded from getting loans, might gain access to it. In this respect, finance might be an equalizer for people with talents, ambition, and persistence. Rajan and Zingales (2003, p. 92) argue that the revolution in financial markets is "opening the gates of the aristocratic clubs to everyone," as

* Research Department, World Bank, 1818 H Street, NW, Washington, DC 20433; E-mail gclarke@worldbank.org; corresponding author.

$\dagger$ Research Department, World Bank, 1818 H Street, NW, Washington, DC 20433; Guanghua School of Management, Peking University, Beijing 100871, China; E-mail lxu1@worldbank.org.

‡ Research Department, World Bank, 1818 H Street, NW, Washington, DC 20433. E-mail hzou@worldbank.org.

We are grateful for suggestions of two anonymous referees. We thank Jerry Caprio, Robert Cull, Ross Levine, and Mattias Lundberg for comments. We are especially grateful to Thorsten Beck for early collaboration in this project, help in collecting and compiling data, and many useful discussions. The findings, interpretations, and conclusions expressed herein are those of the authors and do not necessarily reflect the views of the International Bank for Reconstruction and Development/The World Bank and its affiliated organizations, or those of the Executive Directors of The World Bank or the governments they represent. The World Bank does not guarantee the accuracy of the data included in this work.

Received October 2003; accepted June 2005.

${ }^{1}$ For the relationship between financial development and growth see, among others, Beck, Levine, and Loayza (2000), Levine, Loayza, and Beck (2000), and Rousseau and Wachtel (2000). 
witnessed by the observation that, "in $1929,70 \%$ of the income of the top $0.01 \%$ of income earners in the United States came from holding of capital .... In 1998, wages and entrepreneurial income made up $80 \%$ of the income of the top $0.01 \%$ of income earners in the United States, and only $20 \%$ came from capital."

Consistent with the idea that financial development might benefit the poor, several theoretical models suggest that income inequality will be lower when financial markets are better developed (Banerjee and Newman 1993; Galor and Zeira 1993). These models show that when investments are indivisible, financial market imperfections perpetuate the initial wealth distribution, resulting in a negative relationship between financial development and income inequality even in the long run.

Although the relation between inequality and financial development could be linear, it is also possible that different mechanisms dominate at different levels of financial sector development, leading to a nonlinear relationship between financial sector development and inequality. Greenwood and Jovanovic (1990) show how financial and economic development might give rise to an inverted U-shaped relationship between income inequality and financial sector development. In their model, income inequality first rises as the financial sector develops but later declines as more people gain access to the system.

The relation between financial development and income distribution is important for policy makers-policy makers want to know how policies affect inequality as well as how they affect growth. Although recent work has established a robust link between financial sector development and economic growth (Levine 1997b), less work has focused on the relation between financial sector development and inequality. Understanding this relationship will allow policy makers to assess whether financial development will improve inequality and when it might be useful in doing so. Because different theoretical models give different predictions about the distributional impact of financial development on inequality, empirical investigation is needed to distinguish between the competing conjectures. $^{2}$

This paper analyzes the relation between the distributional impact of financial intermediary development and income distribution using data from developing and developed countries from between 1960 and 1995. Specifically, we analyze whether financial intermediary development affects income inequality and whether the impact depends on the level of financial development. Because the different mechanisms might be more powerful at different levels of financial sector development, we allow the relationship to be nonlinear. Further, because causation could run either from financial sector development to inequality or from inequality to financial sector development, we control for endogeneity using instruments for financial sector development suggested in the financial sector development-growth literature (see, for example, Levine 1997a, 1999).

Our results show that inequality decreases as financial markets deepen, consistent with Galor and Zeira (1993) and Banerjee and Newman (1993). Although some weak evidence suggests that at low

\footnotetext{
${ }^{2} \mathrm{Li}$, Squire, and Zou (1998) and Li, Xu, and Zou (2000) include financial sector development in regressions looking at factors that affect income inequality. This paper, however, differs from Li, Squire, and Zou (1998) and Li, Xu, and Zou (2000) in several ways. First, neither of these earlier papers is primarily concerned with the impact of financial sector development on inequality. Li, Squire, and Zou (1998) focus on explaining international and intertemporal variations in income inequality, whereas $\mathrm{Li}, \mathrm{Xu}$, and $\mathrm{Zou}(2000)$ focus on the relationship between corruption and inequality (and growth). They do not try to distinguish the various hypotheses as we do here; that is, they assume a linear relationship, and given their focus, they do not run a battery of specifications to examine the robustness of their results. In addition, they do not deal with the endogeneity of financial development, use a different measure of financial sector development that measures financial development less precisely (M2 over GDP), and only include results from a pooled cross section.
} 
levels of financial development inequality might increase as financial sector development increases, that is, that there is an inverted U-shaped relation between financial sector development and income inequality, as suggested by Greenwood and Jovanovic (1990), this second result is not highly robust. We strongly reject the hypothesis that financial development benefits only the rich: We do not find a positive and significant relation between financial development and inequality after controlling for the endogeneity of financial sector development.

In the next section, we briefly review the theoretical literature on the relation between income inequality and financial sector development. We then discuss the data that we use to test the theoretical hypotheses in Section 3. After discussing the empirical specification and some estimation issues in Section 4, we present empirical results in Section 5 and conclude in Section 6.

\section{Theoretical Perspectives on Finance and Inequality}

Although most economists would not expect financial development to widen income inequality in the long run, the popular press, some literature, and Marxist theory often depict financiers as greedy middlemen who serve only the interest of the rich and well connected. Indeed, these views are so common that the first chapter of a recent book defending the free-market system by two famous economists, Rajan and Zingales (2003), is entitled "Does finance benefit only the rich?"

One plausible reason why financial development might benefit the rich, especially when institutions are weak, is that the financial system might mainly channel money to the rich and well connected, who are able to offer collateral and who might be more likely to repay the loan, while excluding the poor. ${ }^{3}$ As financial sectors become more developed, they might lend more to rich households but continue to neglect the poor who are unable to provide collateral. As a result, even as the financial sector develops, the poor remain unable to migrate to urban areas, invest in education, or start new businesses. This tendency might be reinforced if the rich are able to prevent new firms from getting access to finance, preventing them from entering, and reducing the ability of the poor to improve their economic lot. If this were the case, we would expect to see a positive relation between financial development and income inequality-at least at some levels of financial development. We call this story the inequality-widening hypothesis of financial development.

Although the previous arguments suggest that high-income households might benefit more from financial sector development than low-income households, this is not necessarily the case. As financial markets become deeper, and access to finance improves, households that did not previously have access to finance might be the main beneficiaries. Because poor households cannot invest in human and physical capital or bear the start-up costs associated with starting a new business using only their own resources, they will be unable to do so unless they can borrow. In contrast, rich households are able to draw on their own resources for investment whatever the level of financial sector development. Therefore, capital constraints might be less binding for rich households at any level of financial sector development, and so they might gain less when these constraints are loosened.

Several recent theoretical models have formalized this intuition, suggesting that capital market imperfections might increase income inequality during economic development. Banerjee and Newman (1993) and Galor and Zeira (1993) suggest that capital market imperfections and

\footnotetext{
${ }^{3}$ This paragraph mainly draws from Rajan and Zingales (2003), chapter 1.
} 
indivisibilities in investment in human or physical capital may lead to divergence of income for the rich and the poor even in the long run. Further, depending on the initial wealth distribution, these imperfections might mean that income inequality persists even in the long run.

Galor and Zeira (1993) construct a two-sector model with bequests between generations, where agents who make an indivisible investment in human capital can work in a skill-intensive sector. However, given capital market imperfections, only individuals with bequests larger than the investment amount or who can borrow will be able to make this investment. This results in income inequality that is perpetuated through bequests to the next generation. In their model, an economy with capital market imperfections and an initially unequal distribution of wealth will maintain this inequality and grow more slowly than a similar economy with a more equitable initial distribution of wealth. Similarly, Banerjee and Newman (1993) construct a three-sector model, in which two of the technologies require indivisible investment. Because of capital market imperfections, only rich agents can borrow enough to run these indivisible, higher-return technologies. Once again, the initial distribution of wealth has long-run effects on income distribution and growth in the presence of capital market imperfections. With all else remaining equal, these models suggest that countries with larger capital market imperfections, that is, higher hurdles to borrow funds to finance indivisible investment, should have higher income inequality. Consequently, we should observe a negative relationship between financial development and income inequality. We call this hypothesis the inequality-narrowing hypothesis of financial development.

Offering a related, but different, perspective on these basic ideas, Greenwood and Jovanovic (1990) present a theoretical model that has elements of both ideas. In their model, agents operate the more profitable, but more risky, of two technologies only when they can diversify risk by investing in financial intermediary coalitions. However, the fixed costs (e.g., membership fees) associated with these coalitions prevent low-income individuals from joining them. Assuming that poor individuals save less and thus accumulate wealth more slowly, income differences between (high-income) members of intermediary coalitions and (low-income) outsiders will widen, resulting in an increase in income inequality. However, because the entrance fee is fixed, all agents eventually join these coalitions, resulting in an eventual reversal in the upward trend. Consequently, Greenwood and Jovanovic's (1990) model predicts a hump or inverted U-shaped relationship between income inequality and financial sector development, with income inequality first increasing and then decreasing before eventually stabilizing in the long run as more people join financial coalitions. We call this hypothesis the inverted U-shaped hypothesis of financial development.

There are, thus, quite different predictions about the relation between financial intermediaries and income inequality. Yet distinguishing among these three hypotheses is important. If the inequality-narrowing hypothesis is correct, improving the access to finance would reduce inequality and benefit low-income households in rich and in poor countries alike. In contrast, if the inverted Ushaped hypothesis is correct, improving the access to finance might initially worsen income inequality in poor countries, improving it only after the country has passed a certain stage of financial sector development. Finally, if the inequality-widening hypothesis is true, some countries might be trapped in a high-inequality world that would be only worsened by financial sector development. In what follows, we use data from a broad cross section of countries between 1960 and 1995 to assess the empirical validity of the different hypotheses.

It is perhaps useful to note that the inverted U-shaped hypothesis concerns a situation in which the empiricist observes the evolution of income inequality and financial development during the development process. Thus, the relationship would be most likely to show up in short- or medium-run time-series or panel data. In contrast, testing the inequality-widening and 
inequality-narrowing hypotheses might require long-run data, such as cross-sectional data based on long time series.

\section{Data}

This section describes our indicators and data for financial intermediary development and income inequality as well as the set of conditioning information. Table 1 presents descriptive statistics and correlations. ${ }^{4}$ The income inequality data are based on a new data set of Gini coefficients compiled by Deininger and Squire (1996) and extended by Lundberg and Squire (2000). Although the original data set contained over 2600 observations, Deininger and Squire (1996) and Lundberg and Squire (2000) limited the data set by imposing several quality conditions. First, all observations had to be from national household surveys for expenditure or income. Second, the coverage had to be representative of the national population. Third, all sources of income and uses of expenditure had to be accounted for, including own consumption. ${ }^{5}$

To explore whether there is an inverted U-shaped relationship between economic development and income inequality, as proposed by Kuznets (1955), we regress the logarithm of the Gini coefficient on the log of real per capita GDP and its square. Figure 1 shows the result for the panel sample. The graph suggests the existence of an inverted U-shaped curve. However, this graph does not control for alternative explanations of income inequality, such as financial depth.

The recent literature on the relationship between financial intermediary development and economic growth has developed several indicators to proxy for the ability of financial intermediaries to identify profitable projects, monitor and control managers, ease risk management, and facilitate resource mobilization. We concentrate on credit to the private sector by financial intermediaries over GDP (private credit). This indicator, which comprises credit to private firms and households from banks and nonbank financial intermediaries (but which excludes central banks as lenders and government and state-owned enterprises as borrowers), seems a good proxy variable for the extent to which private sector agents have access to financial intermediation (as in Greenwood and Jovanovic 1990) or access to loans (as in Banerjee and Newman 1993, Galor and Zeira 1993). Many recent studies that have looked at the effect of financial sector development on economic growth have used this variable as a measure of financial sector development, showing that growth is faster in countries where private credit is higher (see, for example, Beck, Levine, and Loayza 2000; Levine, Loayza, and Beck 2000).

To assess the robustness of results, we use a second measure of financial development: claims on the nonfinancial domestic sector by deposit money banks divided by GDP (bank assets). In contrast to private credit, this measure excludes credits by nonbank financial intermediaries and includes credit to governments and state-owned enterprises.

\footnotetext{
${ }^{4}$ The sample includes Algeria, Argentina, Australia, Austria, Belgium, Burkina Faso, the Bahamas, Bolivia, Botswana, Brazil, Cameroon, Canada, Chile, China, Colombia, Costa Rica, Cote d'Ivoire, Cyprus, Denmark, Dominican Republic, Ecuador, Egypt, El Salvador, Finland, France, Gabon, Gambia, Germany, Ghana, Greece, Guatemala, Guinea Bissau, Guyana, Honduras, Hong Kong (China), Indonesia, India, Ireland, Italy, Jamaica, Japan, Jordan, Kenya, Korea, Luxembourg, Madagascar, Malawi, Mali, Malaysia, Mexico, Morocco, Netherlands, New Zealand, Nicaragua, Niger, Nigeria, Norway, Pakistan, Panama, Paraguay, Peru, Philippines, Portugal, Senegal, Sierra Leone, Singapore, South Africa, Spain, Sri Lanka, Sudan, Sweden, Thailand, Trinidad and Tobago, Tunisia, Turkey, Uganda, United Kingdom, United States of America, Venezuela, Zambia, and Zimbabwe.

${ }^{5}$ To account for different sampling methods, we adjust the data using a method suggested by Deininger and Squire (1996) and also applied by Li, Squire, and Zou (1998) and Lundberg and Squire (2000). Specifically, Deininger and Squire (1996) find a systematic difference of 6.6 points between the means of income-based and expenditure-based Gini coefficients. We, therefore, add 6.6 points to the expenditure-based Gini coefficients.
} 
Table 1. Descriptive Statistics

\begin{tabular}{|c|c|c|c|c|c|c|c|c|c|}
\hline & $\begin{array}{l}\text { Gini } \\
\text { Coef. }\end{array}$ & $\begin{array}{l}\text { Private } \\
\text { Credit }\end{array}$ & $\begin{array}{l}\text { Bank } \\
\text { Assets }\end{array}$ & $\begin{array}{l}\text { Initial GDP } \\
\text { per Capita }\end{array}$ & $\begin{array}{l}\text { Risk of } \\
\text { Exprop. }\end{array}$ & $\begin{array}{c}\text { Ethno-linguistic } \\
\text { Fract. }\end{array}$ & $\begin{array}{l}c \text { Gov't } \\
\text { Cons. }\end{array}$ & $\begin{array}{l}\text { Inflation } \\
\text { Rate }\end{array}$ & $\begin{array}{l}\text { Mod Sect. } \\
\text { Val. Add. }\end{array}$ \\
\hline $\begin{array}{l}\text { Number of } \\
\text { observations }\end{array}$ & 205 & 205 & 205 & 205 & 205 & 163 & 205 & 205 & 205 \\
\hline Mean & 38.4 & 44.9 & 42.4 & 5552 & 7.3 & 0.25 & 14.3 & 1.15 & 86.0 \\
\hline Minimum & 22.4 & 1.6 & 2.5 & 160 & 3.3 & 0.00 & 5.6 & 1.00 & 43.3 \\
\hline Maximum & 61.1 & 202.8 & 132.1 & 20,367 & 10 & 0.86 & 27.9 & 3.22 & 99.6 \\
\hline $\begin{array}{l}\text { Gini } \\
\quad \text { coefficient }\end{array}$ & 1.00 & & & & & & & & \\
\hline Private credit & $\begin{array}{r}-0.38 \\
(0.00)\end{array}$ & 1.00 & & & & & & & \\
\hline Bank assets & $\begin{array}{r}-0.48 \\
(0.00)\end{array}$ & $\begin{array}{c}0.86 \\
(0.00)\end{array}$ & 1.00 & & & & & & \\
\hline $\begin{array}{l}\text { Initial GDP } \\
\text { per capita }\end{array}$ & $\begin{array}{r}-0.59 \\
(0.00)\end{array}$ & $\begin{array}{c}0.69 \\
(0.00)\end{array}$ & $\begin{array}{c}0.61 \\
(0.00)\end{array}$ & 1.00 & & & & & \\
\hline $\begin{array}{l}\text { Risk of } \\
\quad \text { expropriation }\end{array}$ & $\begin{array}{r}-0.59 \\
(0.00)\end{array}$ & $\begin{array}{c}0.64 \\
(0.00)\end{array}$ & $\begin{array}{c}0.66 \\
(0.00)\end{array}$ & $\begin{array}{c}0.78 \\
(0.00)\end{array}$ & 1.00 & & & & \\
\hline $\begin{array}{l}\text { Ethnolinguistic } \\
\text { fractionalization }\end{array}$ & $\begin{array}{c}0.11 \\
(0.15)\end{array}$ & $\begin{array}{c}-0.38 \\
(0.00)\end{array}$ & $\begin{array}{l}-0.35 \\
(0.00)\end{array}$ & $\begin{array}{c}-0.45 \\
(0.00)\end{array}$ & $\begin{array}{r}-0.50 \\
(0.00)\end{array}$ & 1.00 & & & \\
\hline $\begin{array}{l}\text { Government } \\
\text { consumption }\end{array}$ & $\begin{array}{r}-0.48 \\
(0.00)\end{array}$ & $\begin{array}{c}0.33 \\
(0.00)\end{array}$ & $\begin{array}{c}0.37 \\
(0.00)\end{array}$ & $\begin{array}{c}0.61 \\
(0.00)\end{array}$ & $\begin{array}{c}0.50 \\
(0.00)\end{array}$ & $\begin{array}{c}-0.36 \\
(0.00)\end{array}$ & 1.00 & & \\
\hline $\begin{array}{l}\text { Inflation } \\
\text { rate }\end{array}$ & $\begin{array}{c}0.32 \\
(0.00)\end{array}$ & $\begin{array}{c}-0.28 \\
(0.00)\end{array}$ & $\begin{array}{r}-0.30 \\
(0.00)\end{array}$ & $\begin{array}{r}-0.22 \\
(0.00)\end{array}$ & $\begin{array}{r}-0.21 \\
(0.00)\end{array}$ & $\begin{array}{c}-0.03 \\
(0.72)\end{array}$ & $\begin{array}{r}-0.21 \\
(0.00)\end{array}$ & 1.00 & \\
\hline $\begin{array}{l}\text { Modern sector } \\
\text { value added/GDP }\end{array}$ & $\begin{array}{c}-0.25 \\
(0.00) \\
\end{array}$ & $\begin{array}{c}0.55 \\
(0.00) \\
\end{array}$ & $\begin{array}{c}0.54 \\
\quad(0.00) \\
\end{array}$ & $\begin{array}{c}0.68 \\
(0.00) \\
\end{array}$ & $\begin{array}{c}0.67 \\
(0.00) \\
\end{array}$ & $\begin{array}{c}-0.68 \\
(0.00)\end{array}$ & $\begin{array}{c}0.47 \\
(0.00)\end{array}$ & $\begin{array}{c}-0.06 \\
(0.43)\end{array}$ & 1.00 \\
\hline $\begin{array}{l}\text { Private Credit, clai } \\
\text { Levine (2000). } \\
\text { Bank Assets, claim } \\
\text { and Levine (2000). } \\
\text { Risk of Expropriati } \\
\text { indicate that risk is lower } \\
\text { Ethnolinguistic Fra } \\
\text { from } 0 \text { to } 1 \text {, with higher } \\
\text { Government Const } \\
\text { Inflation Rate, log } \\
\text { Modern Sector V. }\end{array}$ & $\begin{array}{l}\text { ims on the } \\
\text { ns on dome } \\
\text { tion, index } \\
\text { r. Source: } \\
\text { actionalizat } \\
\text { values ind } \\
\text { umption, } \mathrm{g} \\
\text { difference } \\
\text { alue Adde }\end{array}$ & $\begin{array}{l}\text { Gini coeffi } \\
\text { pita GDP; } \\
\text { private sec } \\
\text { estic nonfil } \\
\text { indicating } \\
\text { PRS Grou } \\
\text { tion, avera } \\
\text { licating gre } \\
\text { government } \\
\text { e of Consur } \\
\text { ed/GDP, va }\end{array}$ & $\begin{array}{l}\text { financial sec } \\
\text { risk of exp } \\
\text { up (2003). } \\
\text { age value c } \\
\text { eater fracti } \\
\text { th consump } \\
\text { umer Price } \\
\text { value addec }\end{array}$ & $\begin{array}{l}\text { Deininger an } \\
\text { oayza et al. (1 } \\
\text { nancial institutic } \\
\text { ctor by deposit } \\
\text { propriation thro } \\
\text { of five indices } \\
\text { ionalization. So } \\
\text { ption as share o } \\
\text { Index. Source: } \\
\text { d of service ar }\end{array}$ & $\begin{array}{l}\text { nd Squire ( } \\
\text { 1999). } \\
\text { ions divide } \\
\text { it money b } \\
\text { rough confi } \\
\text { s of ethnol } \\
\text { ource: Lev } \\
\text { of GDP. S } \\
\text { e: Internati } \\
\text { and indust }\end{array}$ & $\begin{array}{l}\text { (1996) and Lund } \\
\text { ed by GDP. Sour } \\
\text { panks divided by } \\
\text { issation or forcec } \\
\text { linguistic fraction } \\
\text { vine, Loayza, an } \\
\text { source: World B } \\
\text { onal Monetary } \\
\text { trial sectors as }\end{array}$ & $\begin{array}{l}\text { dberg and } \\
\text { Irce: Beck, } \\
\text { GDP. Sou } \\
\text { d nationaliz } \\
\text { nalization, } \\
\text { d Beck ( } 20 \\
\text { ank (2004) } \\
\text { Fund (2002 } \\
\text { share of C }\end{array}$ & $\begin{array}{l}\text { Squire (200 } \\
\text { Demirgüç- } \\
\text { urce: Demi } \\
\text { ization. Hig } \\
\text { with value } \\
000) \text {. } \\
\text { ). } \\
\text { GDP. Sour }\end{array}$ & $\begin{array}{l}003 \text { ). } \\
\text { z-Kunt, and } \\
\text { iirgüç-Kunt } \\
\text { gher values } \\
\text { ues ranging }\end{array}$ \\
\hline
\end{tabular}

We use private credit rather than the ratio of money and quasimoney (M2) to GDP (M2), a measure commonly used to measure financial sector development (King and Levine 1993; Levine and Zervos 1998), for several reasons. First, the ratio of M2 to GDP includes the liabilities of central banks in addition to banks and other financial intermediaries. Second, it includes credit to governments and state-owned enterprises. Because of this, it is a less clean measure of financial sector development than private credit.

Our sample shows a large variation in financial intermediary development. Private credit ranges from 2\% of GDP in Uganda (1990-1995) to over 200\% in Japan (1990-1995). The indicators of financial intermediary development are positively and significantly correlated (see Table 1). The pairwise correlations indicate that income inequality is lower in countries with deeper financial markets; financial sector development is significantly and negatively correlated with the Gini coefficient. Plotting the logarithm of the Gini coefficient and its fitted value (from the regression of the logarithm of the 


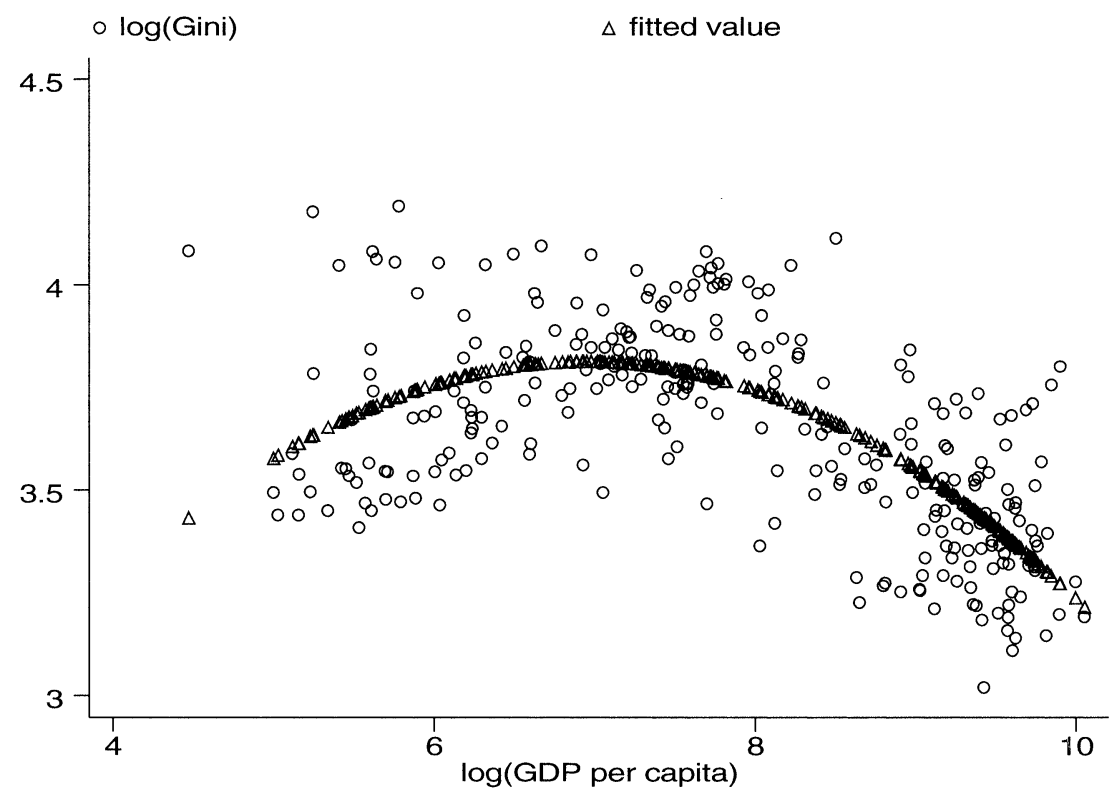

Figure 1. $\log (\mathrm{Gini})$ and $\log (\mathrm{GDP}$ per capita) in a panel of 91 countries. The fitted line is from a regression of $\log (\mathrm{Gini})$ on the log of real per capita GDP and its square. All data are averaged over seven 5-year periods between 1960 and 1995

Gini coefficient on the logarithm of private credit) against the logarithm of private credit, Figure 2 suggests a negative, and possibly nonlinear, relation between the two.

\section{Empirical Framework}

To further explore the relationship between financial intermediary development and income inequality, we estimate the following regression:

$$
\ln \left(\text { Gini Coef }_{\cdot{ }_{\text {it }}}\right)=\alpha_{0}+f\left(\text { Finance }_{i t}\right)+\alpha_{2} C V_{i t}+\varepsilon_{i t} .
$$

As discussed previously, claims on the private sector by financial institutions as percentage of GDP (private credit) and claims on the nonfinancial domestic sector by deposit money banks divided by GDP (bank assets) are the measures of financial sector development. The focus of the analysis is $f\left(\right.$ Finance $_{i t}$ ) which, based on earlier discussions, we assume has the following functional form:

$$
\alpha_{11} \text { Finance }_{i t}+\alpha_{12} \text { Finance }_{i t}^{2} \text {. }
$$

The inequality-narrowing hypothesis predicts $\alpha_{11}<0$ and $\alpha_{12}=0$, the inequality-widening hypothesis predicts $\alpha_{11}>0$ and $\alpha_{12}=0$, and the inverted U-shape hypothesis predicts $\alpha_{11}>0$ and $\alpha_{12}<0$.

In addition to the financial sector variables, we include several variables to control for other factors that might affect inequality. Specifically, we include linear and squared terms of the log of (initial) real per capita GDP to control for a direct "Kuznets effect" of economic development on income inequality that is independent of financial intermediary development. Once controlling for initial GDP, $f\left(\right.$ Finance $_{i t}$ ) captures the effects of finance on steady-state inequality. If the real data do not reflect steady-state situations, initial GDP would capture whatever has been achieved by the force of convergence. However, because per capita GDP is highly correlated with financial sector development, 


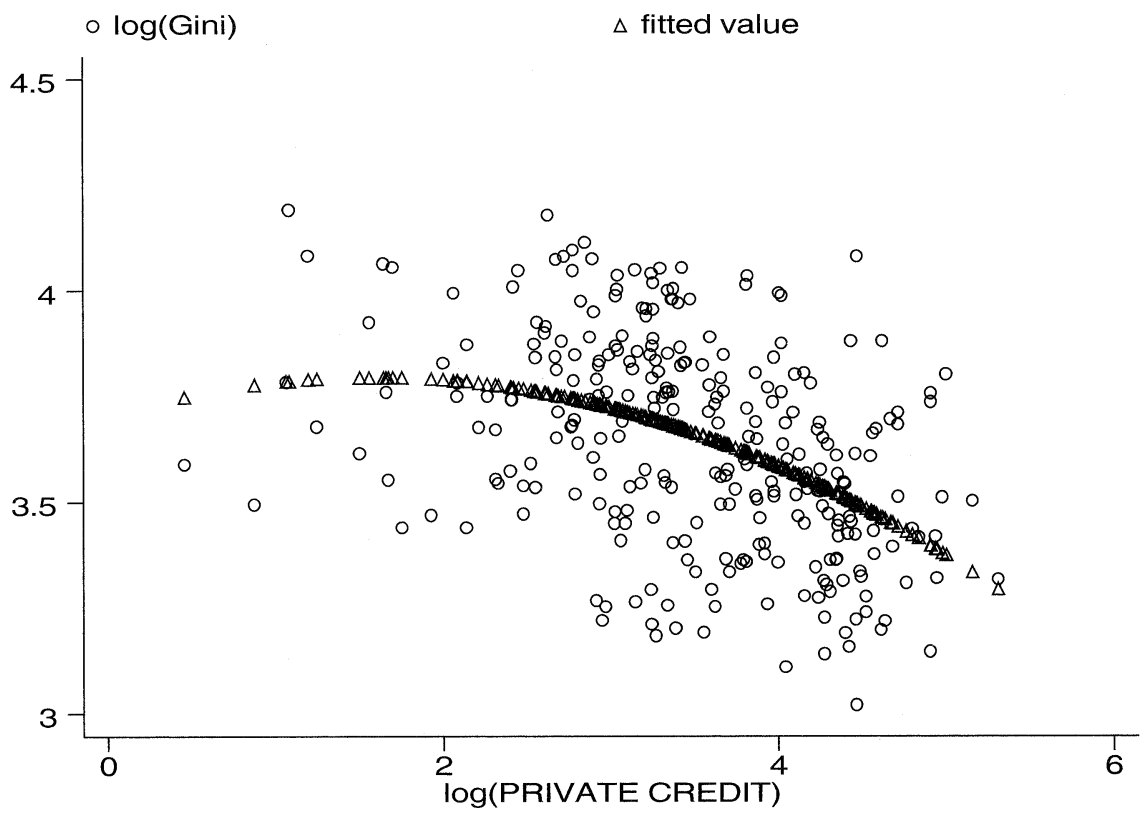

Figure 2. $\log ($ Gini) against $\log$ (Private Credit) in a panel of 91 countries. The fitted line is from a regression of $\log$ (Gini) on the log of Private Credit and its square. All data are averaged over seven 5-year periods between 1960 and 1995.

to make sure that our test of the three hypotheses is robust with respect to the multicollinearity between GDP per capita and financial development, we also estimate the model omitting these variables.

In addition to these measures, we include several additional control variables. We include the inflation rate, conjecturing that monetary instability hurts the poor and the middle class relatively more than the rich because the latter have better access to financial instruments that allow them to hedge their exposure to inflation. ${ }^{6} \mathrm{We}$, therefore, expect inflation to have a positive coefficient.

Additionally, we include measures of government consumption, ethnolinguistic fractionalization, and a measure of the protection of property rights (the risk of expropriation). We might expect income inequality to be higher in countries where ethnic fractionalization is greater if, for example, people are averse to redistribution in countries where ethnic diversity is greater. ${ }^{7}$ This variable was not available across time, and, therefore, it is set equal to the same value for all periods.

It is less clear whether government consumption and property rights protection will increase or decrease income inequality. For example, although the protection of property rights might protect the rich against expropriation by the poor, it could also have the opposite effect, that is, protecting the poor against exploitation by the rich. Similarly, if most redistribution through the tax and transfer system is toward low-income groups, government consumption might result in greater equality. However, it could also have the opposite effect if rich households use their political power to exploit the poor.

\footnotetext{
${ }^{6}$ See, for example, Easterly and Fischer (2001).

${ }^{7}$ Consistent with this, Alesina, Baqir, and Easterly (1999) find that spending on productive public goods (e.g., on schools) is lower in U.S. cities where ethnic diversity is greater. Ethnolinguistic fractionalization was unavailable for many of the countries in our sample. To avoid excessive sample loss, we imputed values based on the other regressors for countries with missing data. Results were robust to using other imputation techniques, including hotdeck imputation (Mander and Clayton 1999) and multiple imputation (Royston 2004). Although the hotdeck approach was used for all regressions, the multiple imputation approach could be used only for OLS regressions. Results were similar in terms of size and statistical significance for the coefficients on the finance variables. Results were also similar for those coefficients when we simply dropped ethnolinguistic fractionalization from the estimation.
} 
Kuznets (1955) suggests that income inequality might depend on the sectoral structure of an economy. Thus, we include a variable representing the share of value added accounted for by services and industry (as opposed to agriculture). The correlation of the modern, that is, nonagricultural sector, share of GDP and GDP per capita indicates that richer countries have larger modern sectors. Although the simple correlation between the modern sector's share of GDP and the Gini coefficient is negative, this appears to be because poorer countries have greater inequality and larger agricultural sectors. After controlling for per capita income, the partial correlation becomes positive and significant.

We conduct the analysis in two ways: a pure cross-sectional analysis, using data averaged over the entire period between 1960 and 1995, and a panel data analysis using five-year panels. The cross-sectional analysis might capture the long-term relationship between finance and inequality, offering a way of testing the long-term relationship featured in the inequality-narrowing and inequality-widening hypotheses. In contrast, the panel analysis might examine the process of comovement between finance and inequality and, therefore, might be a more appropriate setup in which to test the inverted U-shaped hypothesis.

Following the convention of most cross-country empirical panel studies, the panel analysis splits the sample period 1960 to 1995 into seven nonoverlapping 5-year periods. We use 5-year periods rather than shorter time spans because although financial intermediary data are available on a yearly basis for most countries in our sample, they might be subject to business cycle fluctuations that are controlled for by averaging over longer time periods. All panel regressions include time dummies to account for structural differences across periods. To take account of the panel structure of the data, we present results from random effects estimation.

Estimating Equation 1 using ordinary least squares (OLS) (or random effects) estimation might introduce bias because OLS does not allow for the possibility of reverse causality-that is, for the possibility that inequality affects the provision of financial services-something suggested in some of the theoretical models. For example, in Greenwood and Jovanovic's (1990) model, the initial distribution of wealth affects who is able to join financial intermediary coalitions and, therefore, might affect the size of the financial sector. Because we are primarily interested in the effect of financial sector development on income inequality, we use an instrumental variables approach, adopting instruments for financial sector development similar to the ones used in Levine (1997a, 1999), which assesses the exogenous impact of financial intermediary development on economic growth. The instruments are a set of dummy variables proposed by La Porta et al. (1998) that identify the origin of the country's legal system. ${ }^{8}$ We use the legal origin dummy variables, rather than the measures of creditor rights, also proposed by La Porta et al. (1998), because they are available for a wider sample of countries. Several papers have shown that differences in legal origin are significantly related to financial sector development, perhaps because different legal traditions put different levels of emphasis on the rights of property owners or because some systems are more adaptable to exogenous changes than others. ${ }^{9}$ In the empirical analysis, we examine the validity of the instruments using Hansen's J-test to test the overidentifying restrictions. ${ }^{10}$

8 The measures of legal origin were taken from the Global Development Network Growth Database produced by William Easterly and Mirvat Sewadeh (see Easterly 2001).

9 Beck, Demirgüç-Kunt, and Levine (2001) provide an excellent summary of much of the empirical and theoretical literature on this topic. La Porta et al. (1998) show that protection for corporate shareholders and creditors are strongest in common law countries and weakest in French Civil Law countries. La Porta et al. (1997) relate these variables to some measures of capital market development (external market capitalization over GDP, number of listed firms per capita, initial public offerings), showing that they are generally lower in civil law (especially French Civil Law) countries than in common law countries. Beck, Demirgüç-Kunt, and Levine (2001) show that private credit is lower in French Civil law countries than in German Civil Law and common law countries.

${ }^{10}$ In similar regressions of financial sector development on economic growth, Levine $(1997 \mathrm{a}, 1999)$ fails to reject the null hypothesis that the overidentifying restrictions are valid. 


\section{Empirical Results}

\section{Long-Term Relationship from Cross-Sectional Samples}

To test the inequality-widening and the inequality-narrowing hypotheses, we regress the natural $\log$ of the Gini coefficient on linear terms for the measure of financial sector development (private credit) and the additional control variables. Before we control for the possible endogeneity of the measures of financial sector development, the coefficient on private credit is negative but statistically insignificant (see column 1 of Table 2). The coefficient on banks assets is also negative but is statistically significant, indicating that inequality is lower in countries where bank assets are greater as a share of GDP (see column 3 of Table 2). Results for both measures are qualitatively similar when we omit per capita GDP and per capita GDP squared from the regression (see Table 3). These results, as we discussed earlier, do not take into account the issue of the endogeneity of the finance variables.

After controlling for endogeneity using the indicators of legal origin as instruments, the coefficient on private credit remains negative but increases in size and becomes statistically significant (see column 5). Results are similar when bank assets are used as the measure of financial sector development (see column 7). This suggests that financial sector development reduces income inequality, supporting the inequality-narrowing hypothesis and rejecting the inequality-widening hypothesis of financial development. Hypothesis tests reject the null hypothesis that the financial variables are exogenous, favoring the results from the 2 SLS regressions, consistent with the theoretical papers that view financial development as endogenous. ${ }^{11}$ In addition, we are unable to reject the null hypothesis that the legal origin dummies are uncorrelated with the error term after controlling for the other variables, suggesting that they are appropriate instruments (see Hansen J-Statistics in the relevant tables). Based on the coefficient estimates in column 5, a $1 \%$ increase in private credit decreases the Gini coefficient by $0.31 \%$. Results are similar when per capita GDP is omitted (see Table 3), with the point estimate of the parameter slightly smaller at -0.27 .

To test the inverted U-shape hypothesis of financial development, we include squared terms for the measures of financial sector development (see columns 6 and 8). Because the coefficient on the squared term is statistically insignificant in all model specifications, the results do not support this hypothesis. Although the coefficient on the linear term becomes statistically insignificant in both model specifications when the squared term is included, it is important to note that the coefficients on the linear and squared terms are jointly significant at a $1 \%$ level or higher when financial sector development is treated as endogenous. Thus, these regressions suggest that although financial sector development does affect inequality, it appears to do so in a roughly linear fashion. However, the panel data might provide a better way of testing the inverted U-shape hypothesis if panel data better capture short- or medium-run variations in the comovements of financial development and inequality.

After controlling for the endogeneity of the financial sector variables, many of the coefficients on the other control variables are statistically insignificant (see column 5 of the relevant tables). Although the coefficients on the linear and squared terms for initial GDP per capita are statistically insignificant, they are jointly significant in most model specifications. ${ }^{12}$ The positive coefficient on the linear term and the negative coefficient on the squared term suggest an inverted U-shape, with income inequality

\footnotetext{
${ }^{11}$ When we perform a Durbin-Wu-Hausman test using an auxiliary regression (see Davidson and MacKinnon 1993), the null hypothesis that "private credit" is exogenous is rejected at a $1 \%$ significance level ( $p$-value $=0.001$ ). For "bank assets," the null hypothesis that it is exogenous is rejected at a $5 \%$ significance level ( $p$-value $=0.043)$.

${ }^{12}$ They are jointly significant at a $1 \%$ level or higher when bank assets are included, jointly significant at a $10 \%$ level when private credit is included linearly, and statistically insignificant when private credit is included linearly and in squared terms.
} 


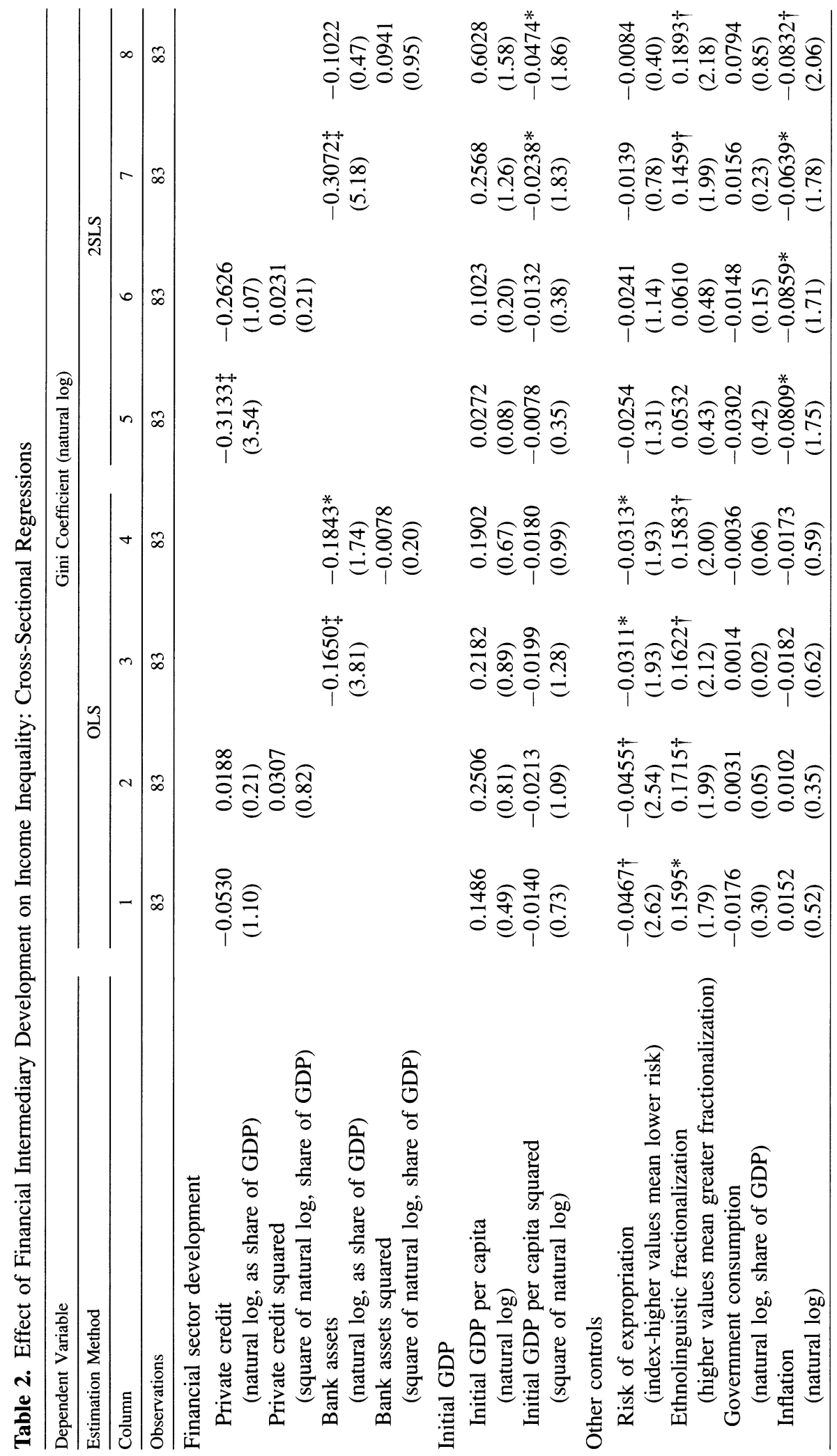




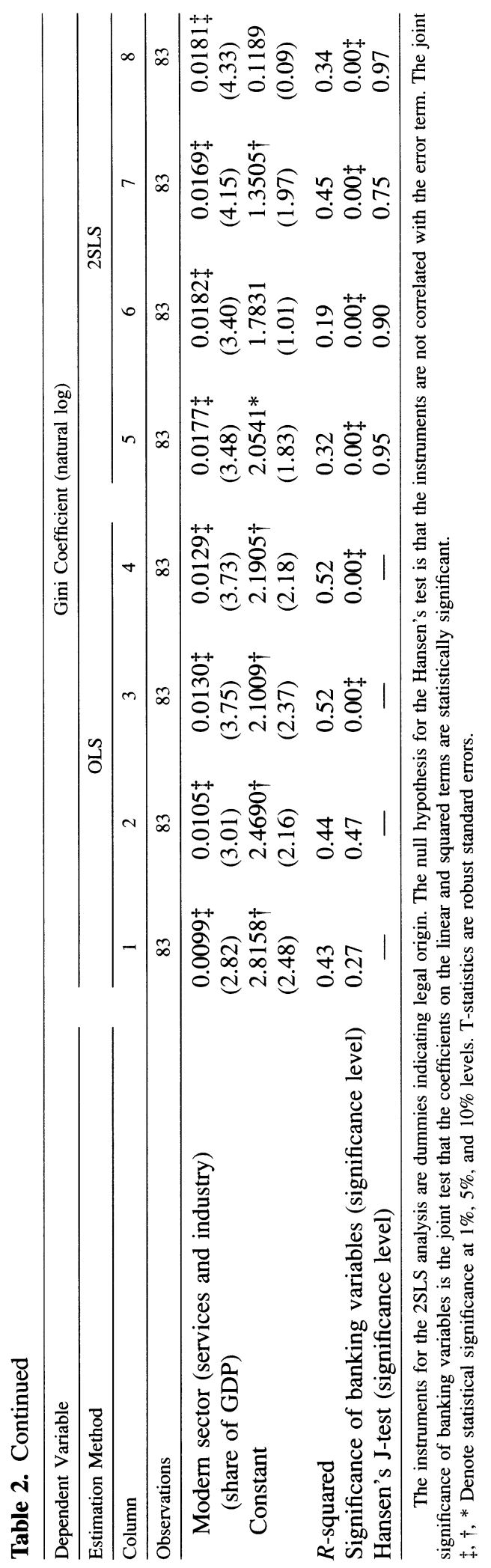




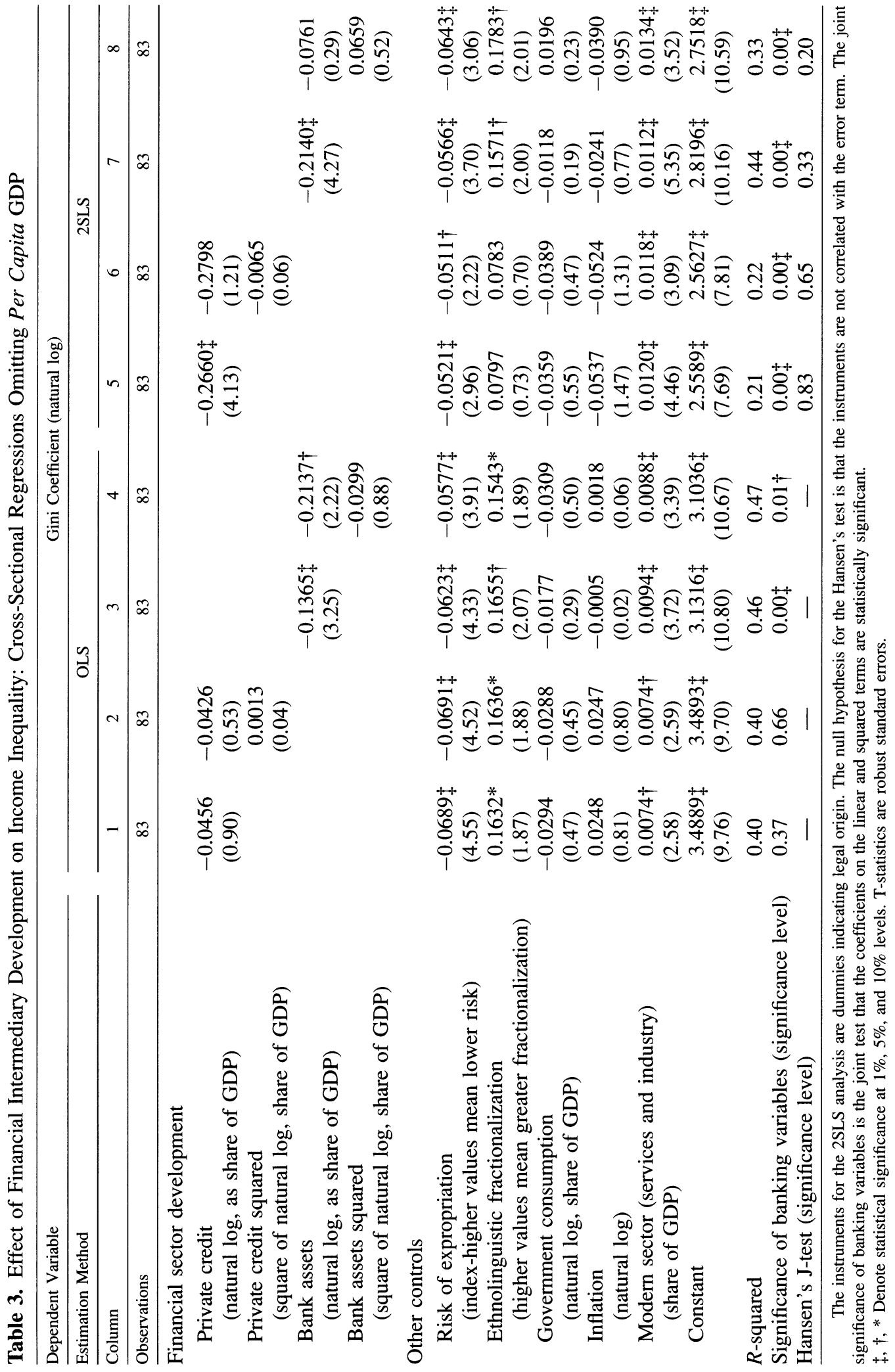


increasing with income at low levels of income and decreasing at high levels. However, the turning point appears to be relatively low-it is less than $\$ 600$ in all regressions in Table 2 and is close to zero when private credit is used as the measure of financial sector development.

When bank assets are used as the measure of financial sector development, the coefficient on ethnolinguistic fractionalization is statistically significant and positive (columns 7 and 8), suggesting that income inequality might be higher in countries with greater fractionalization. This finding supports the conjecture that citizens prefer less redistribution when ethnolinguistic fractionalization is greater. However, this result is not robust because it does not hold when private credit is used as the measure of financial sector development. The negative coefficient on inflation suggests that inequality is generally lower in countries where inflation is greater.

After controlling for other factors that might affect income inequality, including per capita income and financial sector development, the coefficient on the share of the economy accounted for by services and industry, that is, sectors other than agriculture, is positive and statistically significant. This suggests that income inequality is lower in countries where agriculture accounts for a greater share of GDP.

\section{Short- or Medium-Run Results from the Panel Sample}

In addition to the cross-sectional results presented in the previous section, we present results from panel regressions. In addition to providing a useful robustness test, this might also provide better information on the short- and medium-run relationship between finance and inequality. As noted in the previous section, we divide the data up into seven five-year periods. To control for structural differences between periods, all regressions include period dummies. ${ }^{13}$ As a first exercise, we treat the financial variables as exogenous and estimate a random-effects regression.

When private credit is treated as exogenous, its coefficient is small, positive, and statistically insignificant (see column 1 of Table 4). Although the coefficient on bank assets is negative, its coefficient is also statistically insignificant at conventional significance levels (column 2). When squared terms are added to the base regressions, the linear and squared terms are statistically insignificant both singly and jointly.

A first question is whether the model should be estimated as a random-effects model or whether a fixed-effects estimator would be more appropriate. One concern with respect to the fixed-effects estimator is that any cross-sectional variation is removed when country dummies are added to the regression. This might be a problem because although inequality varies greatly between countries, it varies only modestly within countries over time. For example, Li, Squire, and Zou (1998) show that $90 \%$ of the variance in the Gini coefficient in their data (an updated version of which is used in this paper) is cross-country variation, compared with less than $1 \%$ from cross-time variation. ${ }^{14}$ In this respect, fixed effects will remove most of the variation in inequality that we are trying to explain. In addition, including fixed effects might exacerbate problems related to measurement error. This is a particular concern because income distribution is often measured poorly, and although inequality changes slowly over time, measurement error might be quite different in different periods. ${ }^{15}$ Hence,

\footnotetext{
${ }^{13}$ When we added time dummies and tested the joint significance of these dummies, they were statistically significant at a $1 \%$ level or higher in all of the panel specifications in Table 4.

${ }^{14}$ For example, Easterly (2002) suggests that it is unclear whether standard panel methods are appropriate given that income distribution is relatively stable over time.

${ }^{15}$ See Griliches and Hausman (1986) for a discussion of errors in variables in panel regressions.
} 


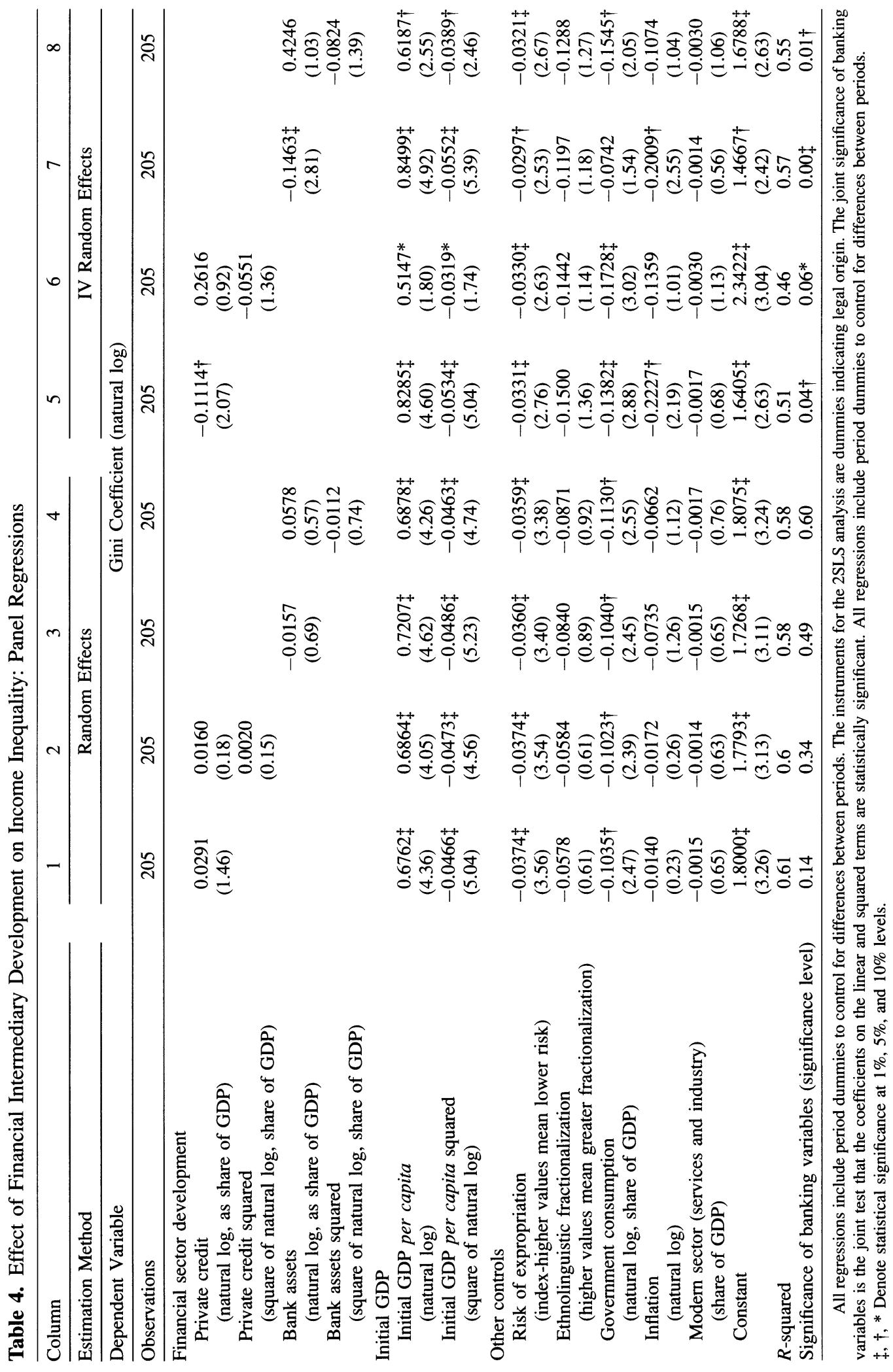


including fixed effects, which remove much of the variation in inequality, might leave us with a small amount of variation in inequality and a larger amount of variation in measurement error.

In practice, the results from the fixed- and random-effect regressions were qualitatively similar. When "private credit" is entered linearly, its coefficient is positive in both the fixed- and randomeffects regressions-although the coefficient is statistically significant in the fixed-effects specification. ${ }^{16}$ A Hausman test fails to reject the null hypothesis that the coefficients from the two models with private credit are systematically different, favoring the random-effects specification for regressions including "private credit." ${ }^{17}$ For bank assets, the results for the financial variables are similar in the fixed- and random-effects models-the coefficient is small and statistically insignificant in both specifications when entered linearly. However, a Hausman test rejects the null hypothesis that the coefficients are not systematically different for the models with "bank assets" included, favoring the fixed effects regressions. ${ }^{18}$ As in the cross-sectional regressions, there is no evidence of a non-linear effect-the coefficients on the squared terms are statistically insignificant in all model specifications.

The results from the cross-sectional regressions and a priori reasoning from existing theoretical models on finance and inequality all suggest that the financial variables might be endogenous. ${ }^{19}$ Therefore, we reestimate the panel regressions allowing for endogeneity. Because legal origin does not change over time, we are unable to estimate instrumental variable regressions that include fixed effects; that is, the instruments are collinear with the country dummies. Therefore, we reestimate the model using a random-effects instrumental variables model (see columns 5 to 8 in Table 4). When the financial variables are entered linearly, the coefficients on the financial sector variables are negative and statistically significant. This is consistent with the cross-sectional results.

When squared terms are included in the regression, the coefficients on the squared terms are statistically insignificant in both regressions for both financial variables. The results thus do not support the inverted U-shaped hypothesis of financial development. However, as before, the coefficients on the linear and squared terms are jointly significant (see final row of Table 4).

Although most of the control variables remain statistically insignificant, the panel results show greater evidence of an inverted U-shape with respect to initial GDP. The coefficients on initial GDP and initial GDP squared are statistically significant and indicate an inverted U-shape. In the IV random-effects model, the turning point is at about $\$ 2300$ in the private credit regression and $\$ 2200$ in the bank asset regressions. Another notable difference is that the coefficient on the risk of expropriation becomes statistically significant and negative, indicating that inequality is greater when the risk of expropriation is greater. ${ }^{20}$

In contrast to the results for the cross section, results for the panel data are slightly different when initial GDP is dropped from the main regression (see Table 5). When the financial variables are treated as endogenous, the coefficients on the linear terms remain statistically significant and negative when

\footnotetext{
${ }^{16}$ Results from fixed-effects regressions are available from authors on request.

${ }^{17}$ The null hypothesis that the country effects are uncorrelated with the additional variables is not rejected at conventional significance levels $(p$-value $=0.20$ ).

${ }^{18}$ The null hypothesis is rejected at a $1 \%$ significance level $(p$-value $=0.00)$.

${ }^{19}$ Although the Durbin-Wu-Hausman test is not available for the random-effects models, similar tests for the panel data when estimated using OLS and 2SLS, that is, as a pooled cross section, also strongly reject the null hypothesis that the financial variables are exogenous. With a Durbin-Hausman-Wu test, the null hypothesis is rejected at a 5\% significance level for bank assets $(p$-value $=0.044)$ and at a $1 \%$ significance level for 'private credit' $(p$-value $=0.000)$. The coefficients from the twostage least-squares model using the pooled cross section are similar in terms of size and statistical significance to the results from the IV random effects model.

${ }^{20}$ Recall that higher values on the index mean lower risk.
} 


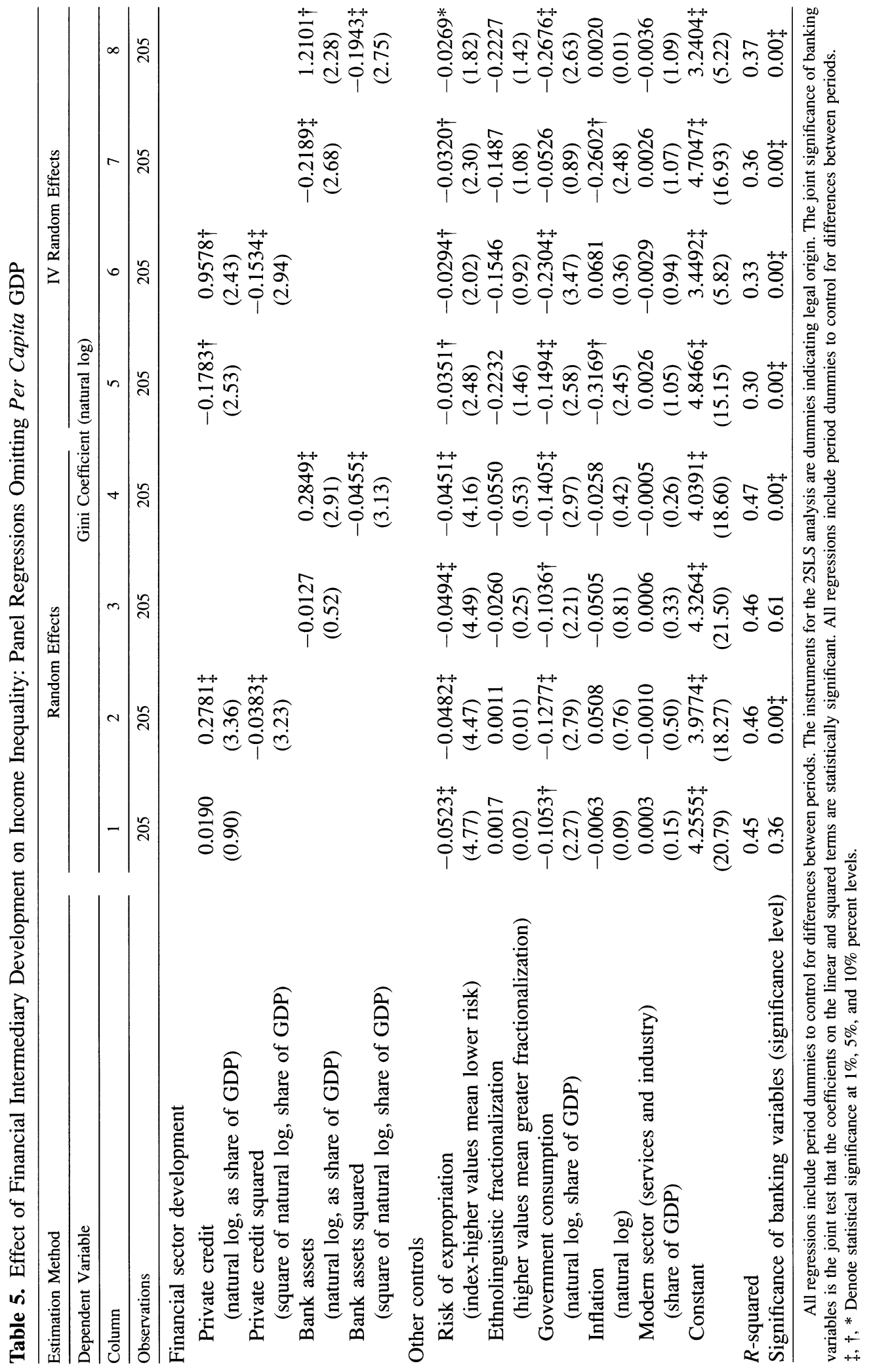


entered linearly. However, the coefficient on the linear term is positive and statistically significant, and the coefficient on the squared term is negative and statistically significant when both linear and squared terms are included. This is broadly supportive of the inverted U-shape hypothesis with inequality first increasing as financial development increases and then decreasing. The point estimates suggest that the turning point is at about when private credit is equal to $22 \%$ of GDP. In 2003, private credit was equal to about $28 \%$ of GDP for low-income countries and $64 \%$ of GDP for middle income countries. ${ }^{21}$ Given the lack of support for the inverted U-shape hypothesis when initial GDP is included, and the support for the hypothesis without the inclusion of initial GDP, and in light of the fact of a close correlation between finance and initial GDP, we conclude that there is some weak support for the inverted U-shape hypothesis when short-term and medium-term variations are considered.

To summarize, after controlling for endogeneity, we find support for the inequality-narrowing hypothesis that inequality is lower in countries with better-developed financial sectors and reject the inequality-widening hypothesis in both panel and cross section. In contrast, we do not generally find strong support for the inverted U-shape hypothesis in the long-run cross-sectional data but do find some weak support for it with short- and medium-run panel data.

\section{Conclusions}

There has been little systematic empirical study on the relationship between finance and inequality. This paper attempts to examine this issue by testing empirically distinct predictions made by alternative theories. Specifically, Galor and Zeira (1993) and Banerjee and Newman (1993) predict a negative and linear relationship between finance and the Gini coefficient (the inequality-narrowing hypothesis), some popular press worry about the inequality-widening effects of financial development, while Greenwood and Jovanovic (1990) suggest a inverted U-shape relationship (the inverted U-shape hypothesis).

Exploring the link between indicators of financial intermediary development and the Gini coefficient in a large cross-country sample for the period 1960-1995, we experiment with both simple specifications and more sophisticated specifications that control for simultaneity. Overall, our results provide some support for the inequality-narrowing hypothesis. We find a significant negative coefficient on the measures of financial intermediary development once we control for endogeneityand hypothesis tests suggest that this is important. In contrast, the results decisively reject the inequality-widening hypothesis. Moreover, while the cross-sectional (long-term) data do not provide much support for the inverted U-shaped hypothesis, the short- and medium-term panel data do provide some weak support for the inverted U-shape hypothesis. Overall, our results suggest that the growth-spurring effects of financial intermediary development are likely to be associated with positive effects on aggregate income distribution as well. ${ }^{22}$

We recognize some limitation of our results, which stem mostly from the limitations of our measure of income inequality. Changes in the Gini coefficient can come about in different ways, by absolute and relative changes in one or several of the different income quintiles. We do not explore the impact that a higher level of financial intermediary development has on the income level of a specific quintile, for

\footnotetext{
${ }^{21}$ Data from World Bank (2004).

${ }^{22}$ See Levine (1997b) for a recent literature survey on this topic. See also Beck, Demirgüç-Kunt, and Levine (2001) for a discussion of more recent results.
} 
instance the poor. Moreover, even results obtained by using quintile data have to be regarded with caution because they do not control for migration between the quintiles over the sample period. To analyze directly the effect of financial development on specific groups of the population, one would have to use disaggregated data, preferably at the household level. This poses new challenges for future research.

\section{References}

Alesina, Alberto, Reza Baqir, and William Easterly. 1999. Public goods and ethnic divisions. Quarterly Journal of Economics 114:1243-84.

Banerjee, Abhijit V., and Andrew F. Newman. 1993. Occupational choice and the process of development. Journal of Political Economy 101:274-98.

Beck, Thorsten, Asli Demirgüç-Kunt, and Ross Levine. 2000. A new database on the structure and development of the financial sector. World Bank Economic Review 14:597-605.

Beck, Thorsten, Ross Levine, and Norman Loayza. 2000. Finance and the sources of growth. Journal of Financial Economics 58:261-300.

Beck, Thorsten, Asli Demirgüç-Kunt, and Ross Levine. 2001. Legal theories of financial development. Oxford Review of Economic Policy 17:483-501.

Davidson, Russell, and James G. MacKinnon. 1993. Estimation and inference in econometrics. Oxford, UK: Oxford University Press.

$\rightarrow$ Deininger, Klaus, and Lyn Squire. 1996. A new data set measuring income inequality. World Bank Economic Review 10:565-91.

Easterly, William. 2001. The lost decades: Developing countries' stagnation in spite of policy reform 1980-1998. Journal of Economic Growth 6:135-57.

$\rightarrow$ Easterly, William, and Stanley Fischer. 2001. Inflation and the poor. Journal of Money, Credit and Banking 33:160-78.

Easterly, William. 2002. Inequality does cause underdevelopment. Unpublished paper, Center for Global Development, Washington, DC.

$\rightarrow$ Galor, Oded, and Joseph Zeira. 1993. Income distribution and macroeconomics. Review of Economic Studies 60:35-52.

$\rightarrow$ Greenwood, Jeremy, and Boyan Jovanovic. 1990. Financial development, growth, and the distribution of income. Journal of Political Economy 98:1076-107.

Griliches, Zvi, and Jerry Hausman. 1986. Errors in variables in panel data. Journal of Econometrics 32:93-118.

International Monetary Fund (IMF). 2002. International finance statistics. Washington DC: International Monetary Fund.

King, Robert G., and Ross Levine. 1993. Finance, entrepreneurship, and growth: Theory and evidence. Journal of Monetary Economics 32:513-42.

$\rightarrow$ Kuznets, Simon. 1955. Economic growth and income inequality. American Economic Review 45:1-28.

$\rightarrow$ La Porta, Rafael, Florencio López-de-Silanes, Andrei Shleifer, and Robert W. Vishny. 1997. Legal determinants of external finance. Journal of Finance 52:1131-50.

$\rightarrow$ La Porta, Rafael, Florencio López-de-Silanes, Andrei Shleifer, and Robert W. Vishny. 1998. Law and finance. Journal of Political Economy 106:1113-55.

Levine, Ross. 1997a. The legal environment, banks, and long-run growth. Journal of Money, Credit and Banking 30:596-613.

$\rightarrow$ Levine, Ross. 1997b. Financial development and economic growth: Views and agenda. Journal of Economic Literature 35:688-726.

$\rightarrow$ Levine, Ross, and Sara Zervos. 1998. Stock markets, banks, and economic growth. American Economic Review 88:537-58.

Levine, Ross. 1999. Law, finance and economic growth. Journal of Financial Intermediation 8:8-35.

Levine, Ross, Norman Loayza, and Thorsten Beck. 2000. Financial intermediation and growth: Causality and causes. Journal of Monetary Economics 46:31-77.

$\rightarrow$ Li, Hongyi, Lyn Squire, and Heng-fu Zou. 1998. Explaining international and intertemporal variations in income inequality. Economic Journal 108:26-43.

$\mathrm{Li}$, Hongyi, Lixin Colin Xu, and Heng-fu Zou. 2000. Corruption, income distribution, and growth. Economics and Politics 12:155-82.

Loayza, Norman, Humberto Lopez, Klaus Schmidt-Hebbel, and Luis Serven. 1999. World saving database. Unpublished paper, World Bank.

Lundberg, Mattias, and Lyn Squire. 2000. The simultaneous evolution of growth and inequality. Unpublished paper, World Bank.

$\rightarrow$ Lundberg, Mattias, and Lyn Squire. 2003. The simultaneous evolution of growth and inequality. Economic Journal 113:326-44.

Mander, Adrian, and David Clayton. 1999. Hotdeck imputation. Stata Technical Bulletin Reprints 9:196-9.

PRS Group. 2003. International country risk guide. East Syracuse, NY: PRS Group.

Rajan, Raghuram G., and Luigi Zingales. 2003. Saving capitalism from the capitalists. New York: Crown Business.

Rousseau, Peter L., and Paul Wachtel. 2000. Equity markets and growth: Cross-country evidence on timing and outcomes, 19801995. Journal of Banking and Finance 24:1933-57.

Royston, Patrick. 2004. Multiple imputation of missing values. Stata Journal 4:227-41.

World Bank. 2004. World development indicators. Washington DC: World Bank. 